\title{
RAZLIKE U TESTOVIMA KOORDINACIJE UČENIKA PETIH RAZREDA OŠ KRALJEVICA - UČENIKA MATIČNE ŠKOLE KOJI IZVODE NASTAVU TJELESNE I ZDRAVSTVENE KULTURE U SPORTSKOJ DVORANI I UČENIKA PODRUČNIH ŠKOLA KOJE NEMAJU SPORTSKU DVORANU
}

\author{
Davor Juriša $^{1}$, Sunčica Vučković ${ }^{1}$ \\ ${ }^{1}$ Osnovna škola Kraljevica
}

\begin{abstract}
Sažetak:
Koordinacija ima svoje zakonitosti razvoja kroz određeno vremensko razdoblje rasta i razvoja djece. $U$ tom vremenskom razdoblju može se upravljanim procesom vježbanja utjecati na poboljšanje koordinacije. Ukoliko se to učini, djeca će u istim uvjetima rada bolje napredovati i tijekom narednog dužeg vremenskog razdoblja. Cilj ovog rada je pokazati razlike u napredovanju dviju grupa učenika s početnim različitim uvjetima rada.
\end{abstract}

Ključne riječi: koordinacija, poligon natraške, vježbanje, uvjeti rada

\section{Uvod}

Koordinacija je sposobnost upravljanja pokretima cijeloga tijela ili dijelova lokomotornog sustava (Bompa, 2006.). Očituje se u brzom i preciznom izvođenju složenih motoričkih zadataka, tj. brzom rješavanju motoričkih problema.

Pretpostavka za razvoj koordinacije je pravovremeno vježbanje, odnosno uvažavanje senzitivnih faza razvoja motorike. Koordinacija ima svoj ubrzani rast od šeste do desete godine života. Do dvanaeste godine zadržava stečenu razinu, a nakon toga pada. Taj pad nakon dvanaeste godine događa se u fazi rasta (Juriša, Vučković 2016.).

Učenici koji imaju nastavu tjelesne i zdravstvene kulture u uvjetima bez sportske dvorane $\mathrm{u}$ startu su zakinuti $\mathrm{u}$ odnosu na učenike koji pohađaju nastavu $\mathrm{u}$ odgovarajućim materijalnim uvjetima. Ukoliko se nedostatak dvorane ne nadoknadi nastavnim pomagalima koja osiguravaju kvalitetan rad u učionici i ukoliko se ne radi po zakonitostima upravljanja procesom vježbanja, izostaju rezultati u poboljšanju koordinacije.

\section{Problem}

Osnovni problem ovog rada bio je utvrditi razliku u vrijednostima testa za procjenu koordinacije učenika razredne nastave koji su polazili nastavu tjelesne i zdravstvene kulture u kvalitetnim uvjetima rada u matičnoj školi i učenika iz područnih škola koji nemaju sportsku dvoranu te adekvatna pomagala pomoću kojih bi vježbanjem $u$ učionici nadoknadili nedostatak sportske dvorane. 


\section{Metode rada}

\subsection{Uzorak ispitanika}

Uzorak ispitanika činili su učenici dvaju razrednih odjela petih razrada Osnovne škole Kraljevica: 9 učenika matične škole u Kraljevici koji su peti razred pohađali u školskoj godini 2005./2006. i 5 učenika iz područnih škola u Šmriki i Križišću koji su peti razred pohađali u školskoj godini 2005./2006.

Svi su učenici prilikom testiranja bili zdravi.

\subsection{Uzorak varijabli}

Za procjenu koordinacije korišten je test poligon natraške (MPN). Test je proveden na početku i na kraju nastavne godine 2005./2006. (Findak i sur.,1996., Metikoš i sur., 1989.). Učenici su testirani na početku nastavne godine (5.i) te na kraju nastavne godine (5.f).

\subsection{Metode obrade podataka}

$\mathrm{Za}$ test poligon natraške (MPN) bile su izračunate aritmetičke sredine (AS), maksimalni rezultati (MAX) i minimalni rezultati (MIN) na početku i na kraju školskih godina (Juriša, Vučković, 2017.).

\section{Rezultati i analiza}

\subsection{Rezultati mjerenja učenika polaznika matične škole u Kraljevici}

\section{Tablica 1}

$\begin{array}{cccc}\text { r.b. } & \text { Matična škola } & \mathbf{5 . i .} & \mathbf{5 . f .} \\ \text { 1. } & \text { IME I PREZIME } & \text { MPN } & \text { MPN } \\ 2 . & \text { M.B. } & 10,20 & 10,9 \\ \text { 3. } & \text { R.B. } & 14,90 & 11,2 \\ 4 . & \text { I.K. } & 17,00 & 17,7 \\ \text { 5. } & \text { I.L. } & 12,30 & 10,2 \\ \text { 6. } & \text { K.P. } & 16,90 & 16,1 \\ \text { 7. } & \text { L.S. } & 17,00 & 10,4 \\ 8 . & \text { K.S. } & 12,40 & 13,3 \\ \text { 9. } & \text { K.Z. } & 19,20 & 17,3 \\ & \text { H.S. } & 14,00 & 15,5 \\ & \text { AS 5. Kraljevica } & \mathbf{1 4 , 8 8} & \mathbf{1 3 , 6 2} \\ & \text { MAX } & 19,20 & 17,70 \\ & \text { MIN } & 10,20 & 10,20\end{array}$

U tablici 1 prikazana je obrada rezultata učenika petog razreda u školskoj godini 2005./2006. koji su polazili nastavu tjelesne i zdravstvene kulture u matičnoj školi u Kraljevici. 


\subsection{Rezultati mjerenja učenika polaznika područnih ̌kola u Šmriki i Križišću}

Tablica 2

$\begin{array}{cccc} & \text { Područne škole } & \text { 5.i. } & \text { 5.f. } \\ \text { r.b. } & \text { IME I PREZIME } & \text { MPN } & \text { MPN } \\ \text { 1. } & \text { L.B. } & 22,40 & 18,9 \\ 2 . & \text { M.M. } & 18,30 & 15,5 \\ \text { 3. } & \text { M.P. } & 18,30 & 18,5 \\ \text { 4. } & \text { L.V. } & 17,10 & 12,2 \\ \text { 5. } & \text { I.V. } & 19,60 & 18,1 \\ & \text { AS 5. Kraljevica } & \mathbf{1 9 , 1 4} & \mathbf{1 6 , 6 4} \\ & \text { AS RH } & 15,10 & 16,10 \\ & \text { MAX } & 22,40 & 18,90 \\ & \text { MIN } & 17,1 & 12,2\end{array}$

U tablici 2 prikazana je obrada rezultata učenika petog razreda u školskoj godini 2005./2006. koji su polazili nastavu tjelesne i zdravstvene kulture u područnim školama u Šmriki i Križišću

\subsection{Razlike rezultata dviju grupa učenika i analiza}

Tablica 3

\begin{tabular}{|l|c|c|}
\hline & \multicolumn{2}{|c|}{ MPN } \\
\hline GRUPA & $\mathbf{5 . i}$ & $\mathbf{5 . f}$ \\
\hline AS 5. Kraljevica & $\mathbf{1 4 , 8 8}$ & $\mathbf{1 3 , 6 2}$ \\
\hline AS 5. područnih škola Šmrika i Križišće & $\mathbf{1 9 , 1 4}$ & $\mathbf{1 6 , 6 4}$ \\
\hline MAX 5. Kraljevica & 19,20 & 17,70 \\
\hline MAX 5. područnih škola Šmrika i Križišće & 22,40 & 18.90 \\
\hline MIN 5. Kraljevica & 10,20 & 10,20 \\
\hline MIN 5. područnih škola Šmrika i Križišće & 17,10 & 12,20 \\
\hline
\end{tabular}

Rezultati prosjeka (aritmetičke sredine) testa MPN u obje mjerene grupe u oba mjerenja pokazuju bolje vrijednosti testa učenika koji su polazili nastavu tjelesne i zdravstvene kulture u matičnoj školi u Kraljevici.

\section{Zaključak}

Na uzorku dviju grupa učenika polaznika matične škole u Kraljevici i učenika koji su nastavu tjelesne i zdravstvene kulture polazili u područnim školama može se zaključiti da je pretpostavka bila točna. Polaznici matične škole postigli su puno bolje rezultate 
u testu za procjenu koordinacije od učenika koji su polazili nastavu tjelesne i zdravstvene kulture u područnim školama.

S obzirom da koordinacija ima svoj ubrzani rast od šeste do desete godine života, ciljano vježbanje djece tijekom petog razreda, kada su još uvijek u senzitivnoj fazi razvoja koordinacije, dovelo je do poboljšanja koordinacije u obje grupe učenika.

Spomenuto razdoblje života najvažnije je u razvoju koordinacije pa treba osigurati materijalne uvjete rada za sve učenike i primijeniti sve zakonitosti upravljanog procesa vježbanja kako bi se tijekom razvojnog razdoblja moglo utjecati na razvoj koordinacije.

\section{Literatura}

1. Bompa, T. (2006.). Periodization - Theory and metodology of trening. Zagreb

2. Findak, V., Metikoš, D., Mraković, M., Neljak, B. (1996.). Norme. Zagreb: Hrvatski pedagoško - književni zbor i Fakultet za fizičku kulturu Sveučilišta u Zagrebu.

3. Juriša D., Vučković, S. (2016.). Odnos rezultata testa MPN za procjenu koordinacije i rasta jedne generacije učenika Osnovne škole Kraljevica kroz vremenski period od 4 godine. Rijeka: ERS.

4. Juriša, D., Vučković, S. (2017.) Razlike u koordinaciji između učenika petih razreda OŠ Kraljevica - učenika polaznika Univerzalne sportske škole i učenika koji nisu polazili program Univerzalne sportske škole. Rijeka: ERS.

5. Metikoš, D., Hofman, E., Prot, F., Pintar, Ž., Oreb, G. (1989.). Mjerenje bazičnih motoričkih dimenzija sportaša. Zagrab: Fakultet za fizičku kulturu Sveučilišta u Zagrebu. 